Meta

Journal des traducteurs

Translators' Journal

\title{
Highlights of Translation Studies in China Since the Mid-Nineteenth Century
}

\section{Shouyi Fan}

Volume 44, numéro 1, mars 1999

Théorie et pratique de la traduction en Chine

The Theory and Practice of Translation in China

URI : https://id.erudit.org/iderudit/002716ar

DOI : https://doi.org/10.7202/002716ar

Aller au sommaire du numéro

Éditeur(s)

Les Presses de l'Université de Montréal

ISSN

0026-0452 (imprimé)

1492-1421 (numérique)

Découvrir la revue

Citer cet article

Fan, S. (1999). Highlights of Translation Studies in China Since the Mid-Nineteenth Century. Meta, 44(1), 27-43. https://doi.org/10.7202/002716ar
Résumé de l'article

Cet article présente les idées des chercheurs chinois en traductologie au cours des 100 dernières années. Dès le commencement de la troisième vague de traduction, des intellectuels patriotes réclament des écoles de traduction afin de relever le défi venu de l'Occident, d'autres introduisent la littérature et la philosophie occidentales en Chine. De nombreux problèmes de traduction surgissent, les traducteurs et les chercheurs discutent des critères à respecter, des méthodes à adopter et des façons d'évaluer la qualité de la traduction. En même temps que la Chine entrait dans une nouvelle ère, la traduction se développait et les études de traduction fleurissaient ; toutes ces activités continuent de progresser et de se développer de façon ordonnée. Une nouvelle vague s'amorce, rapprochant la Chine du monde extérieur. 


\title{
Highlights of Translation Studies in China Since the Mid-Nineteenth Century
}

\author{
shouyi fan \\ Beijing Foreign Affairs College, \\ Beijing, China
}

\begin{abstract}
RÉSUMÉ
Cet article présente les idées des chercheurs chinois en traductologie au cours des 100 dernières années. Dès le commencement de la troisième vague de traduction, des intellectuels patriotes réclament des écoles de traduction afin de relever le défi venu de l'Occident, d'autres introduisent la littérature et la philosophie occidentales en Chine. De nombreux problèmes de traduction surgissent, les traducteurs et les chercheurs discutent des critères à respecter, des méthodes à adopter et des façons d'évaluer la qualité de la traduction. En même temps que la Chine entrait dans une nouvelle ère, la traduction se développait et les études de traduction fleurissaient; toutes ces activités continuent de progresser et de se développer de façon ordonnée. Une nouvelle vague s'amorce, rapprochant la Chine du monde extérieur.
\end{abstract}

\begin{abstract}
This article attempts to highlight the thoughts of some of the prominent figures in translation studies over the past hundred years or so. With the onset of the third wave in translation activities, some patriotic scholars called for the establishment of translator training schools to meet the challenges coming from the West, while others set about introducing Western literature and philosophy into China. In the course of translating, problems cropped up, translators and scholars began to argue about what criteria they should follow, what methods they should use, and how to judge the quality of translation. As China moved into a new era, translation activities boomed and translation studies flourished, all proceeding in an orderly fashion and on a mass scale. A new wave emerged, bringing China closer to the outside world.
\end{abstract}

The third wave of translation started when China was forced to open her doors to the imperialist powers from the West in the mid-nineteenth century. Military invasions, commercial adventures, and cultural influences from the West combined to awaken China's intelligentsia to the fact that China was no longer the Central Kingdom of the world, and that they needed to learn from the West before being able to meet imperialist rivals on equal terms. Liang Qichao (1873-1929), a traditional scholar and reformist, leader of the aborted Hundred-Day Reform, and head of the Jing Shi Academy and Translation Bureau, was perspicacious about the fact that the Western powers knew a lot more about China than China knew about them. He believed this contributed to China's repeated military defeats in the mid-nineteenth century.

\section{FACING THE CHALLENGE}

To remedy the situation in which Western countries had learned much about China by translating Chinese works, while China knew little about Western countries, Liang Qichao came up with two proposals: 
First, let scholars of the country master Western languages from childhood; second, have books written by Westerners translated into Chinese- books that are of practical use to us. Failure to do either will get us nowhere. To realize the first goal, however, we will have to wait for a decade before we are able to see any tangible result. Yet, if we do as suggested in the second proposal, then, once a book is published, every aspiring scholar in China will be able to benefit from it. ([Liang Qichao 1897] Editorial Board 1984a: 9-10)

Liang further argued that the reason European countries had become so strong was that they had translated Greek and Roman classics into their respective languages. For that matter, Peter the Great had collected books from Western countries and had them rendered into Russian, and the Japanese did likewise during the Meiji Restoration. Liang, therefore, considered the translation of books published in Western countries "the most essential of all essential undertakings to accomplish" in speeding up the process of learning from the West and thereby making China strong ([Liang Qichao 1897] Editorial Board 1984a: 10). Liang refuted the notion held by some conservatives that enough Western books had been translated in the 50 years since the opening of China's seaports to Western powers. Liang realized that hundreds of thousands of books were published each year in the West, and that as soon as a new theory came into being, the old theory would die out. Nevertheless, uninformed Chinese scholars often still treasured outdated theories al ready cast aside by Westerners ([Liang Qichao 1897] Editorial Board 1984a: 11). Liang Qichao's observation in this regard was correct, and the translation of new books was needed to replenish China's knowledge about Western developments.

Liang agreed with Ma Jianzhong (1845-1900), a noted scholar and author of China's first grammar book, which he modeled on Latin grammar, over the unsatisfactory state of affairs with regard to works of translation:

Translators of today, with their rudimentary command of the foreign language, are unable to give the proper equivalents to render the nuances of meaning or archaisms of that language; or, though being well-schooled in a foreign language, are only capable of producing a version in Chinese that sounds provincial and slangy, which indicates that they have not yet been properly initiated into the art of translation. If people like them should ever be allowed to do the translating, then the translation they give would often make their readers feel sick at reading such jerky Chinese, and they would have to leave the volume unfinished. Or if we resort to a Westerner who has a smattering knowledge of Chinese for verbal translation of a work, and let the Chinese scholar record the gist of what he has just heard, then very often he would arbitrarily insert his own ideas into the context, which he considers to be inadequately expressed, thus falling short of the expectation of conveying the original idea. It can be seen, therefore, that those who are versed in a foreign language cannot express themselves in proper Chinese, while those who are masters of Chinese cannot understand the foreign language-little wonder the books thus translated are often found to be full of turns of phrase of mixed levels, styled and usages, expressions that are verbose, circumlocutory and erroneous. Such glaring errors have often been spotted and ridiculed by well-informed scholars. ([Liang Qichao 1897] Editorial Board 1984a: 11; see also [ Ma Jianzhong 1894] Editorial Board 1984a: 2)

Faced with this challenge, Liang decided that three things needed to be done right away: first, select the right books for translating; second, lay out rules and conventions for translating; and third, train competent translators. 
What, then are the right books to translate? According to Liang, works dealing with military science could be dropped out of consideration. He believed that, while on the surface the Western powers appeared to have great military strength, what had made them strong was not the building of military force itself, but the development of basic science courses such as mathematics, electronics, chemistry, hydrodynamics, etc., which worked together to contribute to the growth of their military prowess. That was why the Qing (1644-1911) government, though the beneficiary of many works of military science translated in the past, still found itself unable to resist the onslaught of Western invasions ([Liang Qichao 1897] Editorial Board 1984a: 11). In Liang's vision, a stronger China could only emerge from a more substantial foundation in these sciences. It was therefore of primary importance to translate Western charters, constitutions, and civil, criminal and commercial laws, into Chinese so that China could reform its own legal system by modeling itself on Western systems. The next category should include the translation of historical works, including histories of agriculture, commerce and trade, arts and crafts, mining, communication, physics, and of "blue papers" chronicling events of the year. Progress in these fields could be traced and followed and provide references for China's own reforms. Works specific to agriculture, mining, commerce, physics, geometry, algebra, and such should be translated for the purpose of training new generations of professionals. Liang suggested that these works be translated in order of priority, and that some, such as books dealing with agriculture and arts and crafts, be rendered in plain Chinese for easy reading by less well-educated readers ([Liang Qichao 1897] Editorial Board 1984a: 13-15).

The second challenge was to formulate conventions for translators to follow when translating. Most troublesome was the translation of proper names, be they personal names or place names. Often, the same name in an Occidental language could be rendered using various combinations of Chinese characters, so that readers often took them to be different persons or places. This occurred partly because the translators happened to be from different parts of China and spoke different dialects. To allow all translators to follow the same transliteration rules for translating proper names, Liang favoured using the English pronunciation as the norm for representing all sounds in Occidental languages, while Beijing dialect, which was familiar to all speakers of Chinese, could be used for translating foreign names. A grid chart could then be devised to represent all sounds of foreign languages by using particular Chinese characters to map the cells cross-determined by combinations of consonants and vowels in the Chinese language. There were further problems translating terms indicating official or military rank, especially when the ranking systems of the two countries in question did not correspond. In situations where there was no correspondence between a Chinese rank and a foreign rank, transliteration could be employed to create a word for that foreign rank in Chinese. A list of ranking terms had to be made for ease of reference. Translating the names of things that were unheard of in China was a third difficulty. In such cases, either an existing Chinese character which stood for an old thing would be borrowed to designate the new thing, or an entirely new word would be coined for this purpose, with a phonetic component to give the sound of the thing and a cardinal component to indicate its property. For example, the translation of the names of some chemical elements would couple a cardinal form which symbolized a metal [金], with a phonetic component which 
imitates the sound of the first syllable of the name in English, [辛], thus forming a new Chinese character 锌 or "xin" [zinc]. Next was the translation of weights, measures, and currencies. Again Liang proposed that a conversion table be drawn up to offer ready references for translating in either direction. For currencies, a transliteration of the name of the monetary system should be preferred. Coming last in Liang's list of translation challenges is the use of different calendars by different countries, like the Chinese lunar calendar, Christian Gregorian calendar, the Indian calendar, the Islamic calendar, and the Japanese calendar. According to Liang, the mode of numbering years should follow the practice of the country from which the work was being translated, with the corresponding birthday anniversary of the Chinese Sage Confucius and the anniversary of a given dynasty provided as a side-note for easy reference ([Liang Qichao 1897] Editorial Board 1984a: 15-18).

As regards the training of translators, a brief note must be made before discussing Liang Qichao and Ma Jianzhong's proposal. The idea of setting up a translator training school was, in fact, not entirely new, as we mentioned in the opening paragraph above. What Liang and $M$ a were proposing to do, after a hiatus of two decades in which no young people had been sent abroad for training, was to reiterate the need to train bilingual professionals, but inside China. Liang noted that the best translators were those fluent in both the foreign language and Chinese, who were also specialists in the field to which the work pertained. N ext best was the translator who meet two of these three requirements; meeting only one of the three requirements meant that someone could not be trusted with the work of translation ([Liang Qichao 1897] Editorial Board 1984a: 19). Of the three requirements, expertise in a specific discipline outweighed the consideration of mastering both the mother tongue and a foreign language. To train translators and interpreters who could meet these three requirements, translation schools had to be set up. According to Ma Jianzhong, two classes of students could be enrolled. One class would consist of students about 20 years old who had already mastered either English or French. These students would be schooled in classical Chinese, that is, essays by well-known scholars of the Tang (618-907) and Song dynasties (960-1279), and further back to those of the Zhou (476-256 B.C.) and Qin dynasties (221-207 B.C.), while continuing to study their chosen foreign languages. They would be assigned to translate from English or French into Chinese as a way of practicing their translation skills as part of their routine tasks. The other class of students would also be around 20 years of age, but would be well-versed in classic Chinese. They would be tutored in English or French for two years, followed by specialized courses in mathematics, chemistry, physics, law, etc. Before long, these students would be able to translate works from English or French into Chinese competently and accurately ([Liang Qichao 1897] Editorial Board 1984a: 11; see also [M a Jianzhong 1894] Editorial Board 1984a: 2). While Liang Qichao and $\mathrm{Ma}$ Jianzhong endeavored to turn their idea into reality, some mature scholars were already trying their hand at translating.

\section{THE PIONEERS}

At the forefront were two celebrated men of letters, Lin Shu, a traditional Chinese scholar, and Yan Fu, a Western-educated scholar. The former translated mostly fic- 
tion, while the latter focused on philosophical works, but both rendered a great service to the Chinese nation by introducing new ways of thinking.

Although Lin Shu (1852-1924) did not speak any foreign languages, he penned elegant classic Chinese translations of Occidental texts with collaborators who could speak foreign tongues with varying degrees of fluency, but could not translate the works they read into the appropriate Chinese. ${ }^{1}$ Lin published some 222 works of translation, including a few non-fiction texts (Zhang Juncai 1992: 291-323). In many of the prefaces to his translations, Lin included random notes discussing his experiences in translating, and selecting collaborators, and discussing the similarities and differences between Western and Chinese grammar, dialects and styles, as well as the differences between writing and translating.

Lin Shu said in his Preface to Old Curiosity Shop,

I do not speak any Western languages, yet somehow or other, I found myself laboring hard as a translator, working with two or three gentlemen who gave me verbal renditions of the works for translation; I tried to capture the story so related and put it down on paper; when my collaborator stopped, I also stopped writing. Thus, working within the short space of four hours a day, we could manage to produce a six-thousandcharacter long translation. Inevitably a hundred and one errors must have occurred in my translation. However, many generous readers, not showing any contempt for my careless work, bought the books and read them. That is my luck. ([Lin Shu 1907] Luo Xinzhang 1984: 177-178)

Lin was a proliferate translator who worked at incredible speed and enjoyed doing the job.

In his Foreword to YiLin, Lin (1984b) recalled his attempt to find the right collaborator for the translation of a biography of Napoleon Bonaparte. The illustrations in the book depicted the heroic figure of a brave soldier and supreme commander, which made Lin think that the language of the text had to match the man's calibre. He chose a language similar to that used by Sima Qian (?145 or 135-90? B.C.), a historian of the West Han Dynasty (206 B.C.-A.D.24), in his description of the fallen hero Xiang Yu. Lin asked his three long-time collaborators for assistance in translating this work, but each declined. They were wise enough to consider themselves incompetent for the task as they were not men made for writing history. Lin then turned to a Frenchman for help, who likewise balked at the request. This instance shows that a translator cannot handle works of all styles ([Lin Shu 1900] Luo Xinzhang 1984: 161-162).

In Lin's “Remarks about Uncle Tom's Cabin” (1984c), he compared the composition techniques and grammar of Chinese and English, and came to the conclusion that there were as many similarities as differences between the two languages. He seemed very pleased with his translation, for he forewarned prospective readers not to disparage the original work, implying that the artistry of the original work was not as good as the translation ([Lin Shu 1905] Luo Xinzhang 1984: 162-163). Many readers did enjoy his translations- including Zhou Zuoren and Qian Zhongshu who then discovered an interest in translation and began to translate foreign works for publication themselves (Zhou Zuoren 1920; Zhang Juxiang and Zhang Tierong 1986: 301-303; [Qian Zhongshu 1979] Luo Xinzhang 1986: 721-722).

In his "Preface to Ivanhoe" (1984d), Lin made an analogy between narrative writing and tanci, a southern Chinese version of the ballad accompanied by the Pipa, 
an ancient lute-like instrument. He remembered a blind tanci performer from his native province of Fujian, who could mimic the dialects of areas south of the Yangtze, Hunan, Shanxi, Henan, Hebei, or Shandong, that were spoken by the characters in his tanci story. "It is pretty much the same as this work," Lin Shu said. The "retelling of a hero's deeds must be commensurate with the spirit of the hero. The thief 's words must reflect his trade, and the retold utterances of a stubborn mule of a man must match that character" ([Lin Shu 1905] Luo Xinzhang 1984: 167-168). Having captured the distinctive verbal features of each of the speakers in the work, Lin succeeded in breathing life into the characters in his translations.

In his "Preface to Robinson Crusoe" (1984e), Lin noted the difference between translating and writing, saying,

Translating is unlike writing. The writer can write about what he has seen or heard, either in vague expressions or in detailed descriptions, that is to say, he can write about whatever subject and in whatever manner he likes. However, when it comes to translating, the translator is confined to relating what has already been written about, how is it, then, possible for him to adulterate the translation with his own views? When religious inculcations are found in the original text, he must translate them; how can he purge his translation of that discourse just for tabboo's sake? Hence, translation must be done exactly like what has been written in the original. ([Lin Shu 1905] Luo Xinzhang 1984: 169-170)

Although Lin Shu could not read foreign works in the original, he could still detect the minute differences in style of works by different authors. He commented in his "Preface to Dombey and Son" (1984f),

The writer who writes the best English is Sir Walter Scott; the writer who writes the best French is Alexandre Dumas fils, I have translated both of them. However, Scott reads somewhat flaccid in style while Dumas' composition is not compact, both leaving the reader very little room for digesting upon closing the book. However, Charles Dickens alone is able to write skillfully in a manner much the same as playing the go game: the master places a casual piece on the go checkerboard, and after scores of rounds of placement, it goes back to link up with that piece which was seemingly casually positioned before, thus finishing the encirclement for a sweeping victory. The placement of this key piece was made well before his opponent sensed the menace; or in other words, a seed had been inseminated unnoticed even before the embryo was conceived. Because this hint was so apparently insignificant at first reading, the translator would not dare skip over it, however trivial the thing might appear to be, for fear of failure to echo that hint as the story developed. Zhongshu, my collaborator didn't heed this for quite a long while until I told him what I suspected. And so, the two of us went on working away at the book, with tacit understanding - he related the story and I wrote it down. And as the translation grew longer and longer, we were much impressed by the subtleties and abstruseness of the original work, feeling that we were being led step by step into the artistic world created by the author. ([Lin Shu 1909] Luo Xinzhang 1984: 181-182)

Lin's experience is proof that only once a translator becomes totally immersed in a work can he grasp the intention of the text and produce a good translation. A rash translator would often work in great haste and, as a result, his work would fail to exhibit the kind of textual coherence and cohesion that are found in the original.

A complete list of Lin Shu's works can be found in Zhang Juncai (1992: 291-323). According to Zhang Juancai, Lin published a total of 222 works, plus 24 manuscripts. About one third of Lin's translations have some literary value, while the rest are 
simply trash, written by second- or third-rate writers ([Zheng Zhenduo 1924] Luo Xinzhang 1984: 187). Lin even turned Shakespeare's plays into stories, which apparently was not Lin's fault, for as he said "he didn't know it." Not speaking a foreign language himself, Lin was not in a position to choose which books he translated. It was inevitable that some of the books he translated were not of much literary value. Zheng, however, rated Cervantes' Don Quixote, Scott's I vanhoe, and Dickens' Oliver Twist and Old Curiosity Shop among the 40 or so better translations Lin had done ([Zheng Zhenduo 1924] Luo Xinzhang 1984: 189). Lin Shu tried his best to be faithful to the original both in content and style, and put the name of the original author on the front page of the translation, a rare occurrence among the Shanghai translators of his time ([Zheng Zhenduo 1924] Luo Xinzhang 1984: 190). Zheng sums up Lin's contributions to translation in China as follows: at a time when China had been forcibly opened to the outside world for about half a century, Chinese people still knew little about the rest of the world and Lin's translations served as an eye-opener. Although some Chinese were misled into thinking that China was weak because it lacked a modern arsenal, shipyards, railways, and other material things, the Chinese remained proud of their literary heritage and a long list of prestigious historians, essayists, poets and playwrights. Little did they know that there were equally worthy authors, writers, and poets in the "barbarian world". Novel writing had met with the contempt of Chinese men of letters for thousands of years until Lin, a scholar with a classical education, began to translate Western novels in elegant classic Chinese. Lin asserted that some Western authors were comparable to China's Sima Qian, a great historian of the West Han Dynasty. However, Qian Zhongshu (1910) resisted the claim that Lin Shu used classical Chinese in his translation. The Chinese Lin used was not the recondite language of previous millenia, but one made simpler and plainer to understand and use. It was more flexible in syntax and word formation, and allowed colloquialisms, Occidentalized expressions and new coinages to appear in context ([Qian Zhongshu 1979] Luo Xinzhang 1984: 712-719).

Yan Fu (1854-1921), a contemporary of Lin Shu, is considered to be the first person to introduce Western philosophical works to modern China. Unlike Lin Shu who translated with the assistance of others, Yan Fu did the translation himself, having studied military science at a British Navy Academy. For the complete story of Yan Fu's career and accomplishments, read Dr. Kefei Wang's On the Intake of the Western Thought of Political Philosophy in Modern China and Japan- Yan Fu and Japanese Thinkers. Here, I will give just a brief account of Yan's theoretical contribution to China's translation studies, so as to provide a balanced picture of the early part of the modern era. The most important of Yan Fu's contributions was his threecharacter criteria, which stated:

Translating is difficult in three aspects, namely, xin (信 "faithfulness"), da (达 "readability"), and ya (雅 "refinement"). To aspire to perfection in faithfulness is rather difficult. However, to make the translation faithful without being readable is equal to having no translation at all. Hence the relative importance of readability. ([Yan Fu 1898] Editorial Board 1984a: 6)

These are the three-character criteria that have been the subject of debate for almost a century. Yan Fu derived the criteria from his understanding of the differences between Western languages and Chinese. He suggested that the translator: 
grasp the global spirit of the discourse, let the idea become part of your mind and then let the writing brush take care of itself. When it comes to an abstruse text, which cannot be understood all by itself, try to paraphrase it by adding explanatory remarks either afore or aft, to bring out its meaning. This is done for the purpose of making the version readable; to be readable is to be faithful. ([Yan Fu 1898] Editorial Board 1984a: 6)

Yan, as a seasoned translator, knew that readability was essential to make readers read, but it was not sufficient. As Confucius the Sage said: "an utterance that is not refined cannot go afar," Yan Fu concluded that the three points in question should be:

the norms for the craft of composition, and they are, in a similar vein, guidelines for the practice of translating. Hence, besides xin ("faithfulness") and da ("readability"), one should also pay attention to ya ("refinement"). This is not only to let the text reach a wider audience; as a matter of fact, the discourse is so profound and full of nuances of meaning, it can only be made readable with ease by using the lexicons and grammar of the pre-Han period of two millennia ago; whereas it is difficult to use the current vulgar tongue to produce a refined version. ([Yan Fu 1898] Editorial Board 1984a: 6)

He Lin (1902-1991) observed that it was Yan Fu who first put forth the threecharacter criteria, and later translators, whether wittingly or unwittingly, were all guided by these criteria in their practice of translation ([HeLin 1925] Editorial Board 1984a: 117). And in "Ever Since Yan Fu and His Criteria of Translation," Shouyi Fan found correspondences between Yan's criteria and those of A. F. Tyler (1790), which stated that a translation should reproduce the thought of the original completely, the style and manner of writing should be the same as those of the original, and the translation should have the same ease as the original composition (Shouyi Fan 1991: 61-70). All discussion on translation criteria centers around these three aspects, whatever names are used to describe them.

How does the quality of Yan's own translations rate against his own criteria? He Lin repeated the criticisms of his contemporaries in his "Yan Fu's Translations," when he stated that "Evolution and Ethics and Spirit of Law were the worst specimens of translation [...] all because of his irresponsible attitude towards the original authors; he was responsible only to himself" (Fu Sinian); that "his translations were elegant, intelligible to readers of his time" (Cai Yuanpei); that "Yan had managed to make his translations readable thanks to his pretty excellent command of English and Chinese, and his assiduity and punctiliousness" (Hu Shi). Hu Xianxiao thought highly of Yan's translations, saying that Yan's works of translation met all three criteria ([He Lin 1925] Editorial Board 1984a: 117-118). He Lin commented that Yan's earlier translations were done by the "sense method," which was felt to be too free, while his later translations were done by the "literal method," and were less criticized ([He Lin 1925] Editorial Board 1984a: 119).

Yan Fu's translations of Western philosophical works played a large part in inculcating the Chinese mind with ideas of democracy, which hastened the downfall of the last Dynasty of China. Yan Fu's contribution to China's translation studies was equally significant, though the soundness of his theory is still challenged today. One scholar's exposition on translation criteria complemented Yan's three-character criteria; his name was Lin Yutang. 


\section{A RATIONAL INTERPRETATION}

Lin Yutang (1895-1976), a proliferate writer and scholar, wrote an article on translation which gave a perspicacious summary of several controversial issues of the time. According to him there were no ready-made rules to follow in translating; only technical problems which needed to be discussed. One technical problem was the criteria for judging translation, which he considered to be (1) fidelity (忠实 "zhongshi"), (2) mellifluence (通顺 "tongshun"), and (3) aesthetic quality (美 “mei"). The criteria Lin laid out coincide with the three character criteria formulated by Yan Fu, which are (1) faithfulness (信 “xin"), (2) readability (达 "da") and (3) refinement (雅 “ya”). In Lin's opinion, his criterion of "aesthetic quality" covered morethan Yan's "refinement." In both sets of criteria, point (1) concerns the translator's faithfulness to the original, considers a matter of responsibility to the original author; point (2) concerns the translator's fluency in Chinese, which is translator's responsibility to Chinese readers; and point (3) concerns translation's relation to the arts, and raises an artistic responsibility ([Lin Yutang 1933] Editorial Board 1984a: 260).

Other discussions about translation involved random comments on the translator's working experiences, which were superficial observations. But Lin Yutang went further, realizing that translation had to do with linguistics and psychology. Lin saw faithfulness or fidelity as a matter of degree, that is, the quality of translation could be assessed by determining if it was done by the literal method or "dead" method (an "extreme form" of the literal method), or by the "sense" method or "imprudent" method (an "extreme form" of the "sense" method) ([Lin Yutang 1933] Editorial Board 1984a: 261-262). Casting aside the two extreme forms of translation, Lin went on to say that the "literal method" (直译 "zhiyi") and "sense method" (意译 "yiyi") were two misnomers. He believed people could not help taking the "literal method" to mean "word-for-word" literal method, and would then see the word-for-word method as no different than the "dead" method of translating. Similarly, some translators boasted of their imprudently translated texts as being translated by the "sense method," which led some people to think that two sets of rules actually applied to the process of translating, which was not true, according to Lin. "There should be only one applicable criterion, and one appropriate technique too" ([Lin Yutang 1933] Editorial Board 1984a: 262; italics are mine). But Lin went on to talk about "translation by word" and "translation by sentence" as being two ways of translating. "Translation by word" could be used where the translation was deemed correct from the context; and "translation by sentence" had to be used where "translation by word" could not render the "global meaning" of the sentence. The global meaning of a sentence could not be derived a simple summation of the meanings of each and every individual words making up that sentence. It could only be derived after grasping the global idea of the sentence. If the translation happened to be a word-for-word match of the original sentence, so much the better. Otherwise, the meaning of certain individual words had to be ignored in order to catch the global meaning of the sentence ([Lin Yutang 1933] Editorial Board 1984a: 263). To perceive a logical error in Lin's argumentation would be mistaken and imply a failure to follow his logic. According to Lin, it is not a matter of saying "yes" to both "translation by word" and "translation by sentence," but a matter of "yes" or "no." If "translation by word" is correct in a particular context, then "translation by sentence" would be wrong, and vice versa 
([Lin Yutang 1933] Editorial Board 1984a: 264). Hence "one applicable criterion" and "one appropriate technique."

Lin believed that "fidelity" did not necessarily mean a word-for-word correspondence. He thought that the meaning of a word was formed by two parts; "fixed meanings" and "variable meanings," which made it impossible to realize wordfor-word correspondence in all cases ([Lin Yutang 1933] Editorial Board 1984a: 264). He maintained that the translator not only had to transfer the meaning of a sentence, but also the beyond-the-sentence meaning, or what he called the "feeling-tone," which was not an easy task. He further argued that one could not translate all facets of a sentence at the same time - the basic meaning, the spirit, the implication, the style, and the sound. Therefore there was no such thing as absolute faithfulness ([ Lin Yutang 1933] Editorial Board 1984a: 266-267). Next, Lin considered the problem of mellifluence of translation. Like writing in the mother tongue, translating must proceed at the sentence level, that is, the translator must have a "total concept" of the original sentence in mind before turning it into a Chinese sentence, which must be constructed according to Chinese grammar. If the sentence were translated according to the grammar of a Western language, the result could not be regarded as a Chinese sentence. Therefore Lin was opposed to so-called Europeanized sentences, which followed Western grammar too closely to be read smoothly in Chinese. When translating literary works, the translator also had to consider the aesthetic quality of the translation, and make it comparable to that of the original work. The translator therefore had to pay attention to the language used in translating; the language must be beautiful. But, again, this is not an easy thing to do. Poetry, for example, a belle art of the supreme form, cannot be rendered into a different language without losing something ([Lin Yutang 1933] Editorial Board 1984a: 270-271). That something is the style of the original work. Lin thought that the enjoyment of a piece of literary work was not derived from the story but from the way it was told. The manner of telling a story often revealed the writer's style and the task of the translator was to imitate that manner of writing. ([Lin Yutang 1933] Editorial Board 1984a: 271). The problem of style had to do with the discussion of form, which Lin divided into "outer form" and "inner form." The "outer form" refers to the lengths of sentences, rhyming schemes, meter, etc., while the "inner form" refers to those elements that bespeak a writer's idiosyncrasies, mentality, and moods. Lin disdained the use of "free verse" to translate Western poetry, irrespective of the original blank or rhymed verse forms. He called that a "prankish act" ([Lin Yutang 1933] Editorial Board 1984a: 271-272).

\section{THE DEBATE}

In 1930 there was a heated debate between Lu Xun (1881-1936) and Liang Shiqiu (1902-1987) and Zhao Jingshen (1902-1985). Liang Shiqiu accused Lu Xun of making hard translations, which were "next to literal translation. This fashion for literal translation should not be encouraged" ([Lu Xun 1930] Lu H sun 1959: 65). To Liang's accusation, Lu Xun replied,

Owing to my inadequacy as a translator and the limitations of the Chinese language, upon reading through my translation I find it obscure and uneven, and in many places very hard to understand. Yet if I were to cut the redundant phrases, it would lose its 
original flavour. As far as I am concerned, I must either go on producing these hard translations, or produce none at all. I can only hope readers will be willing to make the necessary mental effort to read it. ([Lu Xun 1930] Lu H sun 1959: 65)

However, Liang could not see any difference between hard translation and literal translation. Liang's essay On Hard Translation starts by declaring distorted translations better than literal ones.

It is impossible for a translation to be a complete misrepresentation [...] M aybe unfaithful renderings give a wrong idea of the original, but they give the reader something even though they are mistaken. Even if the wrongness does damage, it is still pleasant to read. ([Lu Xun 1930] Lu H sun 1959: 68)

Liang argued,

Chinese is unlike other languages — that is what makes translation difficult. If the grammar, syntax and vocabulary of two languages were identical, we should have no trouble in translating [...] With intelligibility as our prime criterion, there is no harm in changing the order of sentences, because "making a mental effort" is no fun, and it is doubtful whether "hard translation" can preserve "the essential style of the original." Certainly, if "hard translation" could preserve the essential style of the original that would be a miracle, and we could not accuse the Chinese language of having "limitations." ([Lu Xun 1930] Lu Hsun 1959: 70)

Lu Xun took up the argument by noting the loophole in Liang's reply,

I am not quite such a fool as to look for a foreign language which is like Chinese language, or hope that "the grammar, syntax and vocabulary of the two languages will be identical." But I believe it is relatively easy to translate from languages which have a complex grammar. It is relatively easy, too, to translate from a language akin to your own, although that still requires some effort. Can we say that it is no trouble to translate Dutch into German or Russian into Polish? Japanese is very different from all European languages, yet it is gradually acquiring new methods of expression, so that it is easier to translate now than classical Japanese without losing the flavour of the original. To begin with, of course, you have to "trace your way through the syntax," which is far from "fun" for certain people. But once you are used to this, you assimilate these expressions into your own language. Chinese grammar is even more deficient than that of classical Japanese, but it has known changes too. For instance, the languages used in Ssuma Chien's Historical Records and the Han History are different from that of the Book of History, and our modern vernacular is different again. There have been additions and inventions, as in the Tang Dynasty translations of the emperor's edicts. At the time, much of that "grammar, syntax and vocabulary" was new-fangled; but once people got used to it they could understand it without tracing the words with their fingers. And now that we are dealing with "foreign languages" we may need many new forms of construction - which, to put it strongly, have to be made by "hard translation." In my experience, you can retain the flavour of the original better by this method than by rearranging your sentences; but modern Chinese has its limitations because it is still waiting for new constructions. There is nothing "miraculous" about this. ([Lu Xun 1930] Lu H sun 1959: 70-71)

The point that Lu Xun was making was that time and patience were required for readers to accept expressions borrowed from foreign languages. At first, these foreign expressions might appear quite odd, but people could mentally adapt to the new images. Therefore for some time we needed hard translations, which would in time appear less hard to understand. 
To the accusations of Liang and others, Lu Xun answered,

And I can say with confidence that I never deliberately distort the meaning of any work. When it touches critics on the raw, I laugh. When it touches me on the raw, I put up with it. But I absolutely refuse to make additions or cuts, hence I have always believed in "hard translation." In the long run better translators are bound to appear, who will neither distort the meaning nor give "hard" or "literal" translations; and of course when that happens my translations will be weeded out. All I am trying to do is fill the gap between "having none" and "having better" translations. ([Lu Xun 1930] Lu Hsun 1959: 84)

In another article on translation, Lu Xun made his point more manifest, saying that

It is my hope that many excellent translators will emerge in China; however, if this is unlikely, then all I can do is to give my support to "hard translation." ([Lu Xun 1933] Luo Xinzhang 1984: 289)

We can see that there was a reason for Lu Xun's stubborn adherence to his notion of "hard translation." And, indeed, while many instances of such hard translations have survived into current Chinese language, others have been rejected.

Because Lu Xun was a proponent of literal translation and emphasized that "he would rather be faithful to the original than be fluent in the translation," many people thought that he was against meaning-based free translation and that he himself used the literal method throughout the process of translating. But this was not so. He was for free translation, or at least a combination of both methods. In his "Preface to Little Peter," he said:

For the student of a foreign language to start reading fairy tales shortly after he began to learn would not be improper. However, setting out to translate a fairy tale at this stage would be an inopportune venture to undertake, because, being straitjacketed by the original text, the student would not dare give a free rendition and, as a result, the reader would find it hard to read. This version (itself the translation from the Japanese translation of the German original) has numerous flaws of this kind, therefore, I altered the translation at many places during the time of checking, so that it reads much more smoothly now. ([Lu Xun 1933] Luo Xinzhang 1984: 262-264)

What Lu Xun was talking about in this paragraph was actually a reference to his wife Xu Guangping's translation of Little Peter. It only serves to prove that Lu Xun's approach to translation methods was not of an extreme literalist.

What we have discussed so far are the views of scholar-writer-translators in connection with translation criteria and methods of translating. In the following section, we will learn how the issue is perceived from a stylist's perspective.

\section{THE STYLISTS' VIEW}

Zhu Shenghao (1912-1944) was the first Chinese translator to attempt to translate the complete works of William Shakespeare. Though his early death brought the ambitious project to a halt, his status as a great translator was secured. No writings of his own about translating Shakespeare remain except for a short "Foreword" (1944) he wrote for the translated edition of the Complete Theatrical Works of William Shakespeare. He observed that there had been more cases of translators rendering "hard" translations of Shakespeare than of more careless work. 
... the result of rigidly following the grammar of the original will produce a translation which has lost much of its "spiritual flavour," and worse still, that has been so abstrusely and obscurely translated that nobody can understand it. ([Zhu Shenghao 1944] Editorial Board 1984a: 364)

Zhu set out the goals he himself tried to reach:

I will try to retain the spirit of the original as far as I possibly can; if this cannot be achieved, I will at least try to convey the intentions of the original, using fluent, plain Chinese; as to word-for-word "hard" translations, I dare not venture to go along with. ([Zhu Shenghao 1944] Editorial Board 1984a: 365)

Apparently Zhu was opposed to the word-for-word method of translating. His main consideration was not burdening readers with the hard-to-understand grammar of the alien language.

Wherever the syntax of a sentence in the original text has been found to clash with the grammar of Chinese, I would always mull it over for hours and days until I came up with a version which was totally different in construction from the original, so much so that the intended message of the author had been brought to the foreground without being blurred by obscure Chinese. ([Zhu Shenghao 1944] Editorial Board 1984a: 365)

How did Zhu actually do this? He was not a rough-and-ready sort of translator. When he had finished translating a paragraph, he would revise it with the reader in mind, to see that there were no ambiguities in the paragraph, then read it aloud to check that the version read smoothly and rhythmically. He would muse over a word or a sentence for days before making a choice. Although today we can detect errors of translation here and there in the volumes, these errors appear as occasional blemishes of a great translator.

Fu Lei (1908-1966), another great translator, shared Zhu Shenghao's views on translating. He saw:

differences between two languages in lexicon and syntactic structure, in grammar and idiomatic usage, in rhetorical devices and sayings-all these differences reflect dissimilarities in the modes of thinking of people of different nations, in the range of their perceptions, in their points of view, in their customs and habits, in their social backgrounds, and in their means of expression. ([Fu Lei 1951] Editorial Board 1984b: 80)

Because of these differences, Fu concluded that it was impossible "to capture the linguistic features of a foreign language," without "disrupting the syntactic structures and linguistic peculiarities of the mother tongue" ([Fu Lei 1951] Editorial Board 1984b: 80). However, in his "Letter to Lin Yiliang on Translating Novels" (1951), Fu clarified his point by saying "Not that we can ignore the syntax of the original altogether. What I mean is that we can keep the original syntax as best we can; however, the translation, though appearing novel in grammar, should still be intelligible Chinese." ([Fu Lei 1951] Editorial Board 1984b: 84)

The next significant point Fu Lei raised concerned the style of a translation. $\mathrm{He}$ thought the style of a translation had much to do with the language it used. The style of a translation would often seem unsatisfactory because the language used in the text was "false" or "artificial." Here Fu returned to the issue of whether translators should use classic or vernacular Chinese (i.e. baihua which is the earlier version of today's putonghua, or the standard dialect used throughout China). In Fu's opinion, 
vernacular Chinese is not an ideal medium for translating foreign languages rich in vocabulary and diversified in syntax. He claimed that classic Chinese had an advantage over the vernacular. In this respect, Fu agreed with Zhou Zuoren (1885-1967), Lu Xun's brother, who argued,

By using pianwen (i.e. couplet form which is subject to poetic regulations) intermingled with sanwen (i.e. prose form which is not constrained by such regulations), it is easier to produce a work of translation of satisfactory quality - the translation appears intelligible and does not depart from the original text too far in conveying the meaning. ([Fu Lei 1951] Editorial Board 1984b: 83)

Fu elaborated on Zhou's argument, saying,

Classic Chinese has a long established system, with accepted rules of composition and a rich vocabulary as well; whereas vernacular Chinese, having been just brought over from the folk tongue, has no system nor rules whatsoever to speak of- each and every writer is groping his own way; the result is a shambles. ([Fu Lei 1951] Editorial Board 1984b: 83)

Fu Lei, Zhou Zuoren and others had good reason to hold this view. However, at a time when the May Fourth New Culture M ovement of 1919 was in full swing, with the majority of the populace throwing their weight behind it, Zhou's view was naturally unpopular. Zhou's views might have been true in his time but are less so today, given language's intrinsic propensity to perfect itself over time. Therefore we must give a dialectical interpretation to that battle of words waged more than half a century ago. History often has echoes in modern times and the controversy around the use of plain Chinese or four-character expressions which is going on today is a continuation of the earlier debate. One group of translators now advocates the use of plain, easy to understand forms of language, while another group call for the use of four-character expressions, most of which are classical expressions inserted into the word-stock of putonghua over the years-and the borrowing process continues as writers are constantly digging into the archaic mines of classic language to enrich their vocabulary. However, I don't see much point to carrying on this debate. Whether we should use plain or elevated expressions depends on the context as well as the style of the original. Le propre mot à la propre place should be our guide to deciding which words or expressions to employ to match the macro style of the original work.

Fu Lei, a connoisseur of fine arts, drew an analogy between translating and painting: "What is desired is not formal but spiritual resemblance" ([Fu Lei 1951] Editorial Board 1984b: 80). The focus should be on conveying what has given life to the model being painted on the one hand, and to the original text on the other, rather than mechanically imitating every single detail while losing sight of the sparks of life. Many translators of a younger generation take Fu Lei as their model. Fu's theory of "spiritual resemblance" has since become the predominant guideline for most translators in contemporary China.

Qian Zhongshu (1910- ), a preeminent scholar and writer, though not a professional translator, brought the discussion to a climax by tracing the etymology of "译" [yi], the Chinese word for "translate, translation" to an ancient form made up of "口" [wei] and "化" [hua], with the latter being placed inside the former like this "四"; this word means "translate," that is "translate the alien tongues from countries on 
four horizons and the speeches of birds and animals as well." According to Xu Shen (58?-147?), the lexicologist of the East Han Dynasty (25-211), “化" and "四" were the same word; and therefore "译" [yi] and "化" [hua] were closely related ([Qian Zhongshu 1979] Luo Xinzhang 1984: 696). By relating the word "译" [yi] to the word "化" [hua], Qian found the supreme criterion for translation, which is "化" [hua], i.e. transforming the words of a work written in one language into the words of another country, without the slightest trace of rigid, awkward translation arising from discrepancies in speech habits or linguistic peculiarities, while at the same time keeping the stylistic flavor of the original. If a translator can turn out a work of translation of such excellence, he is considered to have reached the "consummate realm of transmigration" ([Qian Zhongshu 1979] Luo Xinzhang 1984: 696).

\section{NEW WAVE}

On August 19th, 1954, Shen Yanbing (1896-1981) delivered a speech at the National Conference on Literary Translation. As M inister of Culture, Shen was able to command a more comprehensive view of the situation of literary translation in China. He acknowledged the contributions of earlier translators and emphasized the positive role they had played in introducing foreign literature to China, spurring China's N ew Literature M ovement. Viewed from this vantage point, Shen saw the urgent need to translate foreign literary works in order to open the eyes of the Chinese people, and help build socialist China. Shen formulated several guidelines for translators to work by, namely, (1) the work of translation must be conducted in an orderly and planned fashion - translators' associations at both national and local levels needed to be organized for this purpose; lists of classics to be translated had to be drafted in order of literary merit; repetitive translations of the same work by different translators had to be avoided to save human and financial resources; both professional and part-time translators needed to be mobilized and organized for this long-term, national project; (2) literary translation must not be regarded as simply a mechanical process of turning one language into another, a task which anyone with a little knowledge of a foreign language can perform; translators, like writers, must have similar experiences to those of the original authors, so that the translations might sound real; they must be well trained in the art of creation, always trying to learn new ways of expression from real life conversations, thereby enriching their language; they must make a thorough analysis of the author, in term of both thought and style, the society and historical period in which he lived, the themes of the work, etc. before putting pen to paper; therefore translation is an art, like writing itself; and (3) the conduct of criticism and self-criticism should become the order of day for the purpose of improving the quality of translation, cultivating a sense of responsibility on the part of the translator, the reviser and the managing editor; collective work should be encouraged, so that collaborators could pool their skills for better quality translations; ways and means should be found for bringing up a contingent of younger translators to meet the demands of the time ([Shen Yanbing 1954] Luo Xinzhang 1984: 501-507).

Dong Qiusi (1899-1969), creator and editor-in-chief of China's first Translation Bulletin, wrote an article in 1951 calling for the construction of translation theories. He refuted the view that translation was simply a craft. He agreed with others in considering translating as a science in its own right: "That is to say, in the process of 
translating one language into another, the translator can find certain objective laws, which he can go by..." He further suggested,

We should, to begin with, make a study of the linguistic systems of a language, the features and laws governing its growth; of the contents of each individual discipline and its format of presentation, experiences of translating of each age and in each country. By synthesizing the results of our research, we can arrive at a complete system of translation theories. ([Dong Q iusi 1951] Luo Xinzhang 1984: 536-537)

Dong envisaged two steps towards this end. First, that a "common programme" be drafted on the study of major issues such as methods of translating, systems of revision and proofreading, criteria of translation, etc. for adoption by a national conference on translation. Second, that the government sanctioned agency organize experts to do six things: (1) write a history of translation in China, (2) introduce Western books on translation theory to Chinese readers, (3) use scientific linguistic methods to compare Chinese and foreign languages, (4) conduct translation criticism, (5) sum up experiences of translating, and (6) publish a translators' journal. The end products of this national drive would be two books, one on the history of translation in China, and the other on the translatology of China ([Dong Qiusi 1951] Luo Xinzhang 1984: 542-543).

Dong's solution might not have been perfect; but it would give impetus to interested scholars in their collective or individual efforts to make this blueprint materialize. It would be more than three decades before they were able to produce monographs of academic value on the history of translation and theories of translation. The reason: the new wave that was emerging in the mid-fifties was interrupted by a decade of cultural retrogression; the wave rose again with the fall of the radicals. Books of histories of both Chinese and foreign translation studies, of new theories, and of teaching materials have been published: China Translators Journal, Chinese Science and Technology Translators Journal and many other journals have been publishing scores of articles every year (Shouyi Fan 1994: 151-176). We can surmise that the next decade will see a fresh spate of publications, which will be more knowledgebased, more theoretically-oriented, and more reader-friendly.

\section{NOTE}

1. According to Yang Shiji, Zhou Guisheng was the first Chinese scholar to introduce Western literature to China. However, unlike Lin Shu, Zhou could speak both English and French, and he had translated more works than Lin Shu; but he was overshadowed by Lin's fame, and forgotten by readers ([Yang Shiji 1946] Luo Xinzhang 1984: 252-257).

\section{REFERENCES}

Chen, Fukang (1992): History of Chinese Translatology Theories, Shanghai, Shanghai Foreign Language Education Publishing Company.

D ong, Qiusi (1984): “On Building Translation Theories”, Luo (Ed.), Essays on Translation, Beijing, Commercial Press.

Fan, Shouyi (1991): “Ever Since Yan Fu and His Criteria of Translation”, Translation: Theory and Practice- Tension and Interdependence, American Translation Association Scholarly Monograph Series, Volume V, State University of New York at Binghamton.

- - (1994): "Translation Studies in Modern China: Retrospect and Prospect", Target, 6 (2), Amsterdam, John Benjamins. 
Fu, Lei (1984): "Preface to the Retranslated Version of Le Père Goriot", Selected Essays on Translation Studies (1949-1983).

- - (1984): "Letter to Lin Yiliang on Translating Novels", Selected Essays on Translation Studies (1949-1983).

H e, Lin (1984): “Yan Fu's Translations”, Selected Essays on Translation Studies (1894-1948).

Liang, Qichao (1984): “On Translating Western Works", Selected Essays on Translation Studies (1894-1948).

Lin, Shu (1984a): "Preface to Old Curiosity Shop", Essays on Translation.

- - (1984b): "Foreword to YiLin (Translation Journal)", Essays on Translation.

- - (1984c): "Remarks about U ncle Tom's Cabin", Essays on Translation.

- - (1984d): "Preface to Ivanhoe", Essays on Translation.

- - (1984e): "Preface to Robinson Crusoe", Essays on Translation.

- - (1984f): "Preface to Dombey and Son", Essays on Translation.

Lin, Yutang (1984): "On Translation", Selected Essays on Translation Studies (1894-1948).

Lu, H sun (1959): "'Hard Translation' and 'Class Character of Literature,"' Selected Works of Lu H sun, English Edition, Volume 3.

Lu, Xun (1984): “On Translation”, Essays on Translation.

- - (1984): "Preface to the Translated Edition of Little Peter", Essays on Translation.

Lu o, Xinzhang (Ed.) (1984): Essays on Translation, Beijing, Commercial Press.

M a, Jianzhong (1984): "Proposal for Establishing a Translation Academy", Selected Essays on Translation Studies (1894-1948).

M a, Zuyi (1984): A Short History of Translation Studies in China (Prior to the May Fourth M ovement), Beijing, China Translation and Publishing Company.

Qian, Zhongshu (1984): "Lin Shu's Translations", Essays on Translation.

Shen, Yanbing (1984): "Strive for Promoting Literary Translating and Improving Translation Quality-Report Delivered at the National Conference on Literary Translating, August 19th, 1954", Essays on Translation.

Editorial Board (Ed.) (1984a): Translation Bulletin, "Selected Essays on Translation Studies (18941948)", Foreign Languages Teaching and Research Press.

Editorial Board (Ed.) (1984b): Translation Bulletin, "Selected Essays on Translation Studies (19491983)", Foreign Languages Teaching and Research Press.

Wang, Kefei (1996): On the Intake of the Western Thought of Political Philosophy in M odern China and Japan-Yan Fu and Japanese Thinkers, Beijing, China Social Sciences Press.

Yan, Fu (1984): "Translator's Foreword to Evolution and Ethics", Selected Essays on Translation Studies (1894-1948).

Yung, Wing (1909): M y Life in China and America, New York, Henry Holt and Company.

Zhu, Shenghao (1984): "Translator's Preface to the Complete Theatrical Works of William Shakespeare", Selected Essays on Translation Studies (1894-1948).

Zhang, Juncai (1992): Lin Shu: A Biography with Comments, Tianjing, Nankai University Press.

Zh ang, Juxiang and Tierong Zh ang (1986): Source M aterials for Zhou Zuoren Studies, Volume 1, Tianjing, Tianjing People's Publishing Company.

Zheng, Zhenduo (1984): “M r. Qinnan Lin”, Essays on Translation.

Zhou, Zuoren (1920) (1986): "Preface to 'M iscellaneous', Zhang Juxiang and Zhang Tierong, Source Materials for Zhou Zuoren Studies, Volume 1. 